\title{
Helminths of wild hybrid marmosets (Callitbrix sp.) living in an environment with high human activity
}

\author{
Helmintos de saguis (Callithrix sp.) híbridos de vida livre \\ vivendo em ambientes com alta atividade humana
}

\author{
Alexandre de Oliveira Tavela ${ }^{1,2 *}$; Lisieux Franco Fuzessy ${ }^{3}$; Vinicius Herold Dornelas e Silva ${ }^{4}$; \\ Fernanda de Fátima Rodrigues da Silva ${ }^{3}$; Moacir Carretta Junior ${ }^{4}$; Ita de Oliveira Silva ${ }^{3}$; Vanner Boere Souza ${ }^{5}$ \\ ${ }^{1}$ Universidade Federal de Santa Catarina - UFSC, Campus Curitibanos, SC, Brasil \\ ${ }^{2}$ Laboratório de Parasitologia, Departamento de Veterinária, Universidade Federal de Viçosa - UFV, Viçosa, MG, Brasil \\ ${ }^{3}$ Laboratório de Morfofunção Animal, Departamento de Biologia Animal, Universidade Federal de Viçosa - UFV, \\ Viçosa, MG, Brasil \\ ${ }^{4}$ Centro de Triagem de Animais Silvestres, Departamento de Veterinária, Universidade Federal de Viçosa - UFV, Viçosa, MG, Brasil \\ ${ }^{5}$ Departamento de Bioquímica e Biologia Molecular, Centro de Ciências Biológicas e da Saúde, \\ Universidade Federal de Viçosa - UFV, Viçosa, MG, Brasil
}

Received April 11, 2013

Accepted July 4, 2013

\begin{abstract}
The objective of this study was to identify the helminth fauna in hybrid, non-native marmosets, through analysis of fecal samples. The study involved 51 marmosets (genus Callithrix) from five groups living in places with levels of human impact in Viçosa-MG. The marmosets were caught using a multiple-entrance trap and were anaesthetized. Feces were collected, refrigerated and analyzed by means of the sedimentation technique (Hoffmann-Pons-Janner). Eggs and parasites were identified, but not counted. Most of the marmosets (86\%) were parasitized by at least one genus of helminths. Among the infected marmosets, $37 \%$ presented co-infection. The intestinal helminths comprised four different taxa: Primasubulura jacchi, Ancylostomatidae, Prosthenorchis sp. and Dilepididae. P. jacchi and Ancylostomatidae had higher prevalences (> $80 \%$ and $>40 \%$, respectively) and were found in all marmoset groups. Dilepididae species were found in almost all the groups, but only accounted for around 30\% of the marmosets. Prosthenorchis sp. showed a relatively low prevalence $(<10 \%)$ and was only found in one group. Although two parasites are commonly found in marmosets and other primates (P. jacchi and Prosthenorchis sp.), our study is the first record for Ancylostomatidae and Dilepididae. Factors like marmosets' feeding behavior and their contact with humans and other species of nonhuman primates seem to be determinants of infection among marmosets.
\end{abstract}

Keywords: Primasubulura jacchi, Prosthenorchis sp., Ancylostomatidae, anthropozoonosis.

\section{Resumo}

O objetivo do presente estudo foi a identificação da helmintofauna em saguis híbridos e introduzidos, por meio de análises de amostras fecais. O estudo envolveu 51 saguis do gênero Callithrix, de cinco grupos que ocupam áreas com diferentes impactos humanos. Os saguis foram capturados com armadilha de múltiplas entradas e anestesiados. Fezes foram colhidas, refrigeradas e analisadas pela técnica de sedimentação (Hoffmann-Pons-Janner). Ovos e parasitas foram identificados, mas não contados. A maior parte dos saguis (86\%) estava parasitado por, pelo menos, uma espécie de helminto. Do grupo infectado, 37\% apresentou coinfecção. A diversidade helmíntica intestinal incluiu quatro táxons diferentes: Primasubulura jacchi, Ancylostomatidae, Prosthenorchis sp. e Dilepididae. P. jacchi e Ancylostomatidae apresentaram as maiores prevalências ( $>80 \%$ e $>40 \%$, respectivamente) e foram encontrados em todos os grupos. As espécies de Dilepididae apresentaram aproximadamente $30 \%$ da prevalência e foram encontrados em quase todos os grupos. A espécie Prosthenorchis sp. apresentou prevalência relativamente baixa $(<10 \%)$ e foi encontrado somente em um grupo. Considerando que duas das espécies são parasitas comumente descritos para saguis e primatas $(P$. jacchi e Prosthenorchis sp.), este estudo consiste no primeiro registro para Ancylostomatidae e Dilepididae. Fatores como o comportamento alimentar e o contato com o homem e outras espécies de primatas não humanos, parecem ser determinantes na contaminação dos saguis.

Palavras chave: Primasubulura jacchi, Prosthenorchis sp., Ancylostomatidae, antropozoonoses.

\footnotetext{
*Corresponding author: Alexandre de Oliveira Tavela

Universidade Federal de Santa Catarina - UFSC, Rod. Ulysses Gaboardi, Km 3,

Campus Curitibanos, CEP 89520-000, Curitibanos, SC, Brasil

e-mail: alexandre.tavela@ufv.br
} 


\section{Introduction}

Despite growing evidence of the potential importance of parasites in primate populations, it is currently unclear what aspects of anthropogenic changes to the environment facilitate the transmission of infectious agents among wild nonhuman primates or between nonhuman primates and humans (CHAPMAN et al., 2006). Habitat disturbance and fragmentation and proximity to human settlements may influence patterns of parasitism. Such a scenario is quite likely across large parts of the Brazilian Atlantic Forest, and also in the municipality of Viçosa, where the current study was conducted. On the other hand, the proximity of settlements can alter the helminths of nonhuman primates and cause potential zoonotic problems for humans (WENZ et al., 2010; WENZ-MÜCKE et al., 2013).

Among marmosets (genus Callithrix; ERXLEBEN 1777), and especially Callithrix penicillata, natural infection with several protozoans and helminths has been reported (RESENDE et al., 1994). Callithrix penicillata, Callithrix geoffroyi, Callithrix jacchus and hybrids of these species have been introduced into the lowland Atlantic Forest of Viçosa (PEREIRA et al., 1995; MELO, 1999), a region where the endangered species $C$. aurita occurs naturally (HERSHKOVITZ, 1977). Introduced marmosets are of considerable conservation concern because of the possibilities of hybridization with the endangered autochthonous marmoset and of transmission of parasites common to them, since they are in the same habitat and occupy a similar ecological niche (SANTOS SALES et al., 2010).

This investigation aimed to identify helminths in hybrids and introduced marmosets in fragmented forests with high human impact in the municipality of Viçosa, through analysis of fecal samples.

\section{Materials and Methods}

The study was conducted from March 2010 to January 2012 and involved examination of feces collected from 51 marmosets (genus Callithrix): 24 males (20 adults and 4 juveniles) and 27 females (20 adults and 7 juveniles) belonging to five wild groups. Marmosets have been living in a 75-hectares forest fragment, located on the campus of the Federal University of Viçosa, southeastern Brazil (20 $45^{\prime} \mathrm{S}$ and $\left.42^{\circ} 52^{\prime} \mathrm{W}\right)$ for at least three decades. All five groups have some level of human contact: Groups 1 to 4 live in Vila Gianetti, an environment very close to buildings and streets, which leads to high levels of contact between marmosets and humans. Group 5 lives in Belvedere, an environment that is more isolated and better preserved, where marmosets have moderate contact with humans (Figure 1). Contact with humans is characterized by direct touching, humans handing out food to marmosets (bananas and cookies) and garbage exploration by marmosets.

The marmosets were caught using a multiple-entrance trap, weighed, and anaesthetized by means of ketamine hydrochloride (Vetaset, Fort Dodge, Kansas, USA) at a dose of $10 \mathrm{mg} / \mathrm{kg}$ of body mass, and xylazine hydrochloride (Anasedan, Divisão Vetbrands Saúde Animal, SP, Brazil) at a dose of $0.5 \mathrm{mg} / \mathrm{kg}$ of body mass (CARPENTER, 2004). The marmosets were then measured.
After the biological data had been collected, the marmosets were kept in a warm and darkened room until they recovered from the anesthesia. Four hours later, the animals were released at the same location where they had been captured. The skin and fur of all the animals were inspected for ectoparasites with the naked eye and also with a magnifying glass.

During capture and handling of the anesthetized marmosets, feces found in the trap or removed from the animal's rectum were transferred to plastic containers kept under refrigeration. These samples were processed using the sedimentation method (Hoffman-Pons-Janner), which is the one most suitable for diagnosing helminthes in marmosets (RESENDE et al., 1994; SANTOS SALES et al., 2010). The sediment was homogenized; two drops of solution were poured over glass slides, stained with Lugol, and the slides were observed under a standard optical microscope. All the eggs were measured and photographed for identification. The eggs were identified as described by Sloss et al. (1999) and the helminth classification followed Schmidt (1986) for Cestoda, Machado Filho (1950) for Acanthocephala and Vicente et al. (1985) for nematodes. To identify the genera of nematodes, 10 grams of each fecal sample were separated and coprocultures were performed, with subsequent recovery of larvae after 10 days later, by means of the modified Baermann technique (VICENTE et al., 1985; BOWMAN, 2009).

\section{Results}

Most of the marmosets ( $86 \%$ ) were found to be parasitized by at least one species of helminth and $43 \%$ showed co-infection. Despite the parasitism, all the marmosets seemed to be in good physical condition. We detected four different parasite taxa, among which two could be identified to species level, and two to family level only (Figure 2). Two helminth species, P. jacchi and an unidentified species of Ancylostomatidae (Strongylidae), had higher prevalence (> 80\% and > 40\%, respectively) and were found in all groups (Table 1). The unidentified Dilepididae species had around $30 \%$ of prevalence and was found in all groups except group 2 (Table 1). Prosthenorchis sp. had relatively low prevalence $(<10 \%)$ and was found only in the Belvedere group (Table 1). No macroscopically detectable ectoparasites were found.

\section{Discussion}

This is the first description of helminthes in hybrid wild marmosets, and the first description of infection with a species of Dilepididae in Neotropical primates.

The feeding behavior of the marmosets is an important issue in understanding the helminth infection routes. Marmosets feed on arthropods (cicadas, grasshoppers and cockroaches), which may serve as intermediate host for helminths (ALONSO; LANGGUTH, 1989). Since marmosets like tamarins, cebids, pitheciids and atelids, also consume fruits, oral infection through contaminated fruits is conceivable in these species, too (MICHAUD et al., 2003).

Primasubulura jacchi is a nematoda that has been described in primates (SARMIENTO et al., 1999; Saguinus; MICHAUD et al., 2003; Callicebus; PACHECO et al., 2003) and especially in Callithrix 

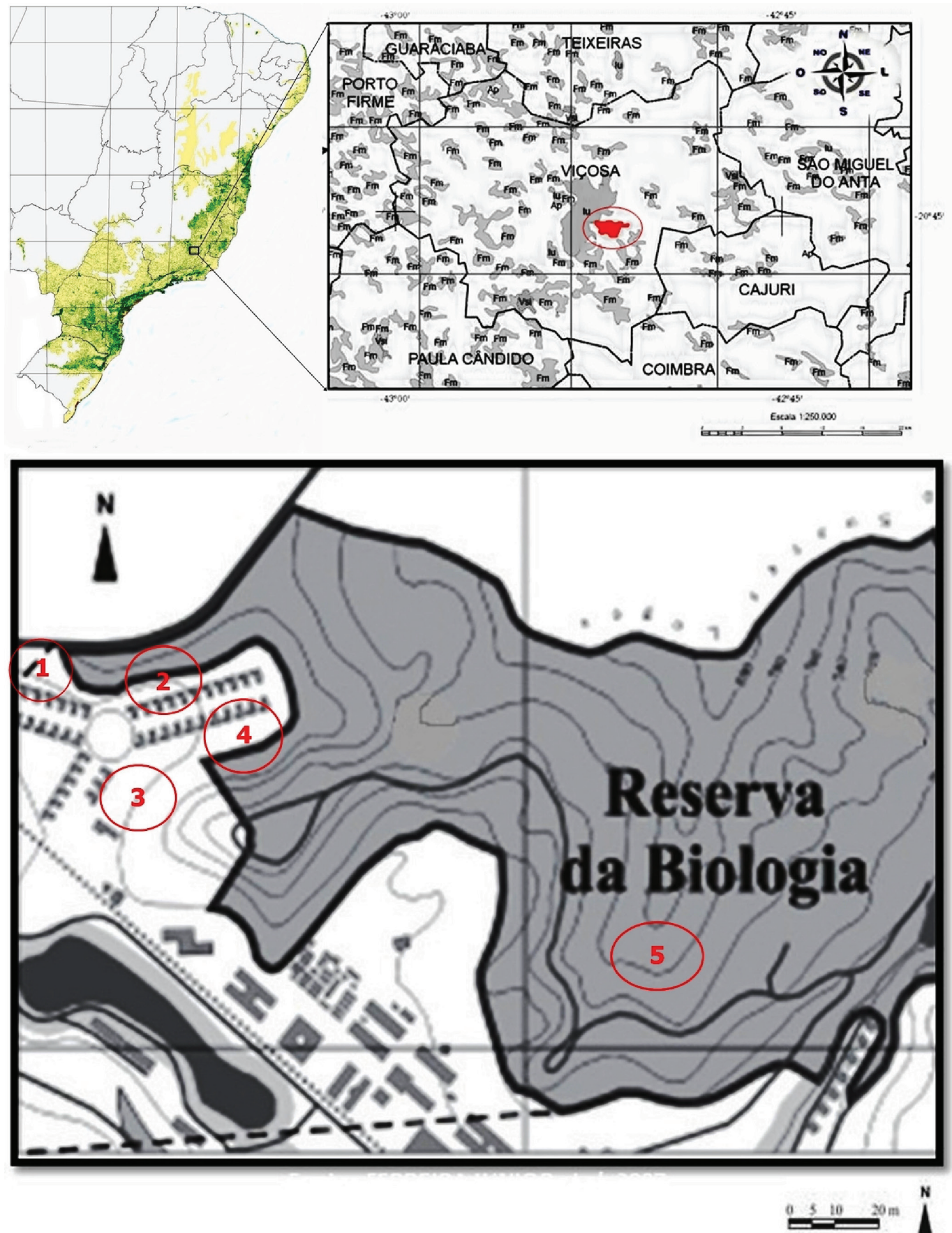

Figure 1. Map of the locations where the marmosets were caught. Group1: Belvedere; Groups 2 to 5: Vila Gianetti, Federal University of Viçosa, Viçosa, MG, Brazil.

(MELO; PEREIRA, 1986; RESENDE et al., 1994; MELO, 2004; SANTOS et al., 2004; SANTOS SALES et al., 2010). More than $80 \%$ of the marmosets in this study were infected with P. jacchi, and this level is very similar to findings from $C$. penicillata caught in Minas Gerais (RESENDE et al., 1994). In that study, it was reported that in some cases, $P$. jacch $i$ could cause ulcerative lesions of the intestinal mucosa and diarrhea. However, in our study, we did not observe any marmosets suffering from diarrhea.
Another nematoda that was found to have high prevalence was an unidentified species of Ancylostomatidae (prevalence of more than 40\%). This helminth family is commonly found parasitizing humans, but previous reports on nonhuman primates only provide sparse information other than listing the presence of the parasites. Therefore, it is unclear whether these reports represent natural infections, captive infections or zoonotic infections from Neotropical primate/human interactions (STUART et al., 1998). 


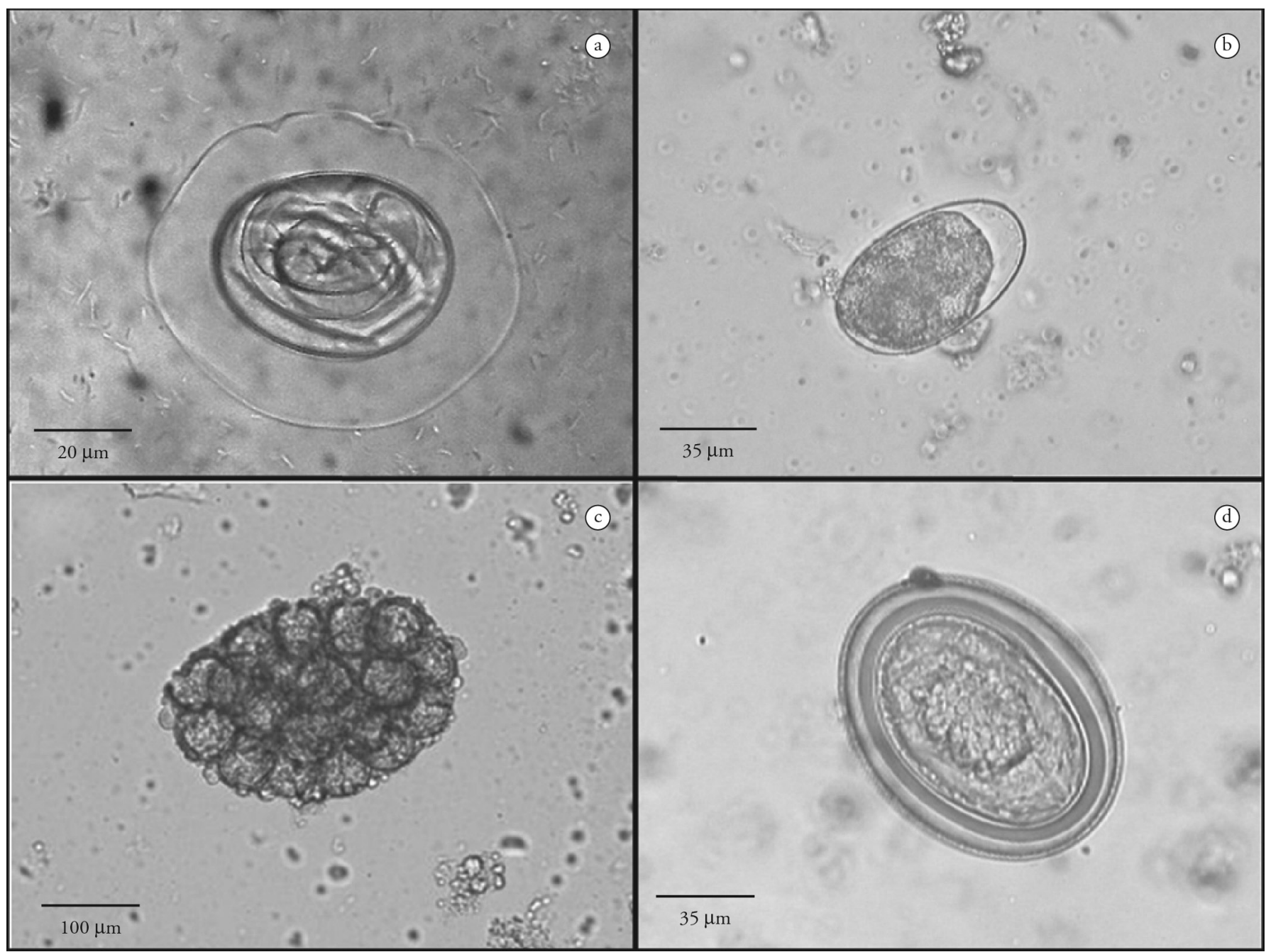

Figure 2. Eggs types found in the wild hybrid marmosets. (a) Primasubulura jacchi; (b) egg from the suborder Strongylida*; (c) Dilepididae; (d) Prosthenorchis sp. ${ }^{*}$ Identified as Ancylostomatidae after recovery of larvae from coprocultures by means of the modified Baermann technique.

Table 1. Helminthological profile of male and female marmosets according to geographical location in the municipality of Viçosa-MG. The table presents total numbers and the percentages of eggs for each gender class obtained after analyses of the feces of marmosets by sedimentation method (Hoffmann-Pons-Janer).

\begin{tabular}{|c|c|c|c|c|c|c|c|c|c|c|c|}
\hline \multirow{4}{*}{$\begin{array}{c}\text { Group } \\
\text { Group } 1 \text { (Belvedere) }\end{array}$} & \multirow{3}{*}{$\begin{array}{l}\text { Gender } \\
\text { Male }\end{array}$} & \multirow{2}{*}{\multicolumn{2}{|c|}{$\begin{array}{c}\text { Number of } \\
\text { animals }\end{array}$}} & \multicolumn{8}{|c|}{ Helminths } \\
\hline & & & & \multicolumn{2}{|c|}{ Dilepididae } & \multicolumn{2}{|c|}{ P. jacchi } & \multicolumn{2}{|c|}{ Ancylostomatidae } & \multicolumn{2}{|c|}{ Prosthenorchis sp. } \\
\hline & & 8 & $62 \%$ & 2 & $33 \%$ & 7 & $88 \%$ & 4 & $33 \%$ & 3 & $38 \%$ \\
\hline & Female & 5 & $38 \%$ & 1 & $20 \%$ & 4 & $80 \%$ & 2 & $40 \%$ & 2 & $40 \%$ \\
\hline \multirow{2}{*}{ Group 2 (Casa 19) } & Male & 4 & $40 \%$ & 2 & $50 \%$ & 3 & $75 \%$ & & & & \\
\hline & Female & 6 & $60 \%$ & & & 4 & $67 \%$ & 1 & $17 \%$ & & \\
\hline \multirow{2}{*}{ Group 3 (Casa 32) } & Male & 4 & $40 \%$ & & & 4 & $100 \%$ & 4 & $100 \%$ & & \\
\hline & Female & 6 & $60 \%$ & 2 & $33 \%$ & 5 & $83 \%$ & 3 & $50 \%$ & & \\
\hline \multirow{2}{*}{ Group 4 (Casa 41) } & Male & 2 & $50 \%$ & 2 & $100 \%$ & 2 & $100 \%$ & 1 & $50 \%$ & & \\
\hline & Female & 2 & $50 \%$ & & & 2 & $100 \%$ & & & & \\
\hline \multirow{2}{*}{ Group 5 (Casa 50) } & Male & 6 & $43 \%$ & 1 & $17 \%$ & 4 & $67 \%$ & 3 & $50 \%$ & & \\
\hline & Female & 8 & $57 \%$ & 4 & $50 \%$ & 7 & $88 \%$ & 4 & $50 \%$ & & \\
\hline \multirow{2}{*}{ Total } & Male & 24 & $47 \%$ & 7 & $29 \%$ & 20 & $83 \%$ & 12 & $50 \%$ & 3 & $13 \%$ \\
\hline & Female & 27 & $53 \%$ & 7 & $26 \%$ & 22 & $85 \%$ & 10 & $37 \%$ & 2 & $8 \%$ \\
\hline
\end{tabular}


The genus Ancylostoma was reported to be one of the most frequent parasites of captive Saimiri sciureus (BOTERO CORREA et al., 2011). A few eggs were observed in free-ranging Leontopithecus rosalia (12\%; MONTEIRO et al., 2003, 2007), and in free-ranging howler monkeys (THOISY et al., 2001). This is the first record of Ancylostomatidae parasitizing Callithrix sp., and it suggests that direct contact between humans and nonhuman primates seems to be involved in case of infection with these hookworms. Human-animal transmission of Ancylostomatidae has frequently been recorded due to proximity and use of common places (gardens, backyards and playgrounds) (OVERGAAUW, 1997; MATTIA et al., 2012; TRAVERSA, 2012). The genus Ancylostoma can cause bronchitis/lung alveolitis and erosion in the intestinal mucosa due to histophagy and hematophagy, leading to formation of intestinal ulcers, followed by microcytic hypochromic anemia and also hypoproteinemia (BOWMAN, 2009). In this study, we did not observe any anemia or diarrhea, but contact with many people is a risk factor that can explain possible infection.

Prosthenorchis sp. is a parasite of wild and captive Neotropical primates (RICHART; BENIRSCHKE, 1963; HORNA; TANTALEÁN, 1990; ARROJO, 2002; MÜLLER et al., 2010). This parasite infects a broad spectrum of hosts, including humans, and it is known that some hosts can tolerate severe infection without clinical signals (KINDLOVITS, 1999). On the other hand, it has also been described in the literature as one of the most severe parasitosis (KINDLOVITS, 1999). It can cause severe and fatal pathological conditions, and infection with this acanthocephalan parasite has been identified as a major cause of illness or death in captive primate colonies (RICHART; BENIRSCHKE, 1963; HORNA; TANTALEÁN, 1990; ARROJO, 2002). The Acanthocephala have an indirect life cycle, and insects of the order Blattaria, which are very common in urbanized environments, from an intermediate host (BOWMAN, 2009). The animals studied, living in urbanized areas, had access to continuous intake of these insects, which could have led to secondary infections, parasite loads and highly imbalanced hostparasite relationships. Similarly, Wenz et al. (2010) reported higher prevalence of Prosthenorchis elegans in tamarins (genus Saguinus) living close to a human village and a research camp.

This study provides the first record of parasitism by a species of Dilepididae in marmosets. This family of cestodes (110 genera, 753 species; BONA, 1994) is cosmopolitan and mainly infects birds (DIDYK; BURT, 1998), with a lower number of genera parasitizing fish (SCHOLZ; SALGADO-MALDONADO, 2001) or mammals, like dogs, foxes, cats and humans (Dipylidium caninum; McCARTHY; MOORE, 2000). Our results show that the presence of humans in the areas where the marmosets were living was the determinant for the prevalence of this cestode, because its presence is directly associated with use of these areas by domestic dogs, which are reservoirs for the Dilepididae family of helminths and their intermediate hosts, fleas of the genus Ctenocephalides.

Hybrid animals may be more prone to infection by a wider variety of parasites than pure-bred animals (fish, DUPONT; CRIVELLI, 1988; mouse, SAGE et al., 1986; MOULIA et al., 1991, 1993; MOULIA, 1999; macaques, GOTOH et al., 2001; marmoset, SANTOS SALES et al., 2010). Our investigation suggests that there is high prevalence of parasitism in hybrid marmosets, but all the marmosets were in good physical condition. Nevertheless cohort studies and comparisons with parental species are necessary in order to elucidate the degree of vulnerability of marmosets to infectious parasites.

Parasitic diseases constitute a serious public health problem in developing countries. Fragmentation of natural habitats increases the risk of unrecognized transmission of human pathogens to marmosets and other primates, through direct contact with humans and their pets (MICHAUD et al., 2003; CARVALHOFILHO et al., 2006). On the other hand, as invasive species, Callithrix spp. could present a threat to the conservation of native species and to human health.

\section{Acknowledgements}

The authors would like to thank CNPq, Capes and Fapemig for financial support and grant concession and the anonymous reviewers for comments on the manuscript.

\section{References}

Alonso C, Langguth A. Ecologia e comportamento de Callithrix jacchus (Primates: Callitrichidae) numa ilha de floresta Atlântica. Rev Nordestina Biol 1989; 6: 105-137.

Arrojo L. Parásitos de animales silvestres em cautiverio en Lima, Perú. Rev Peru Biol 2002; 9(2): 118-120.

Bona FV. Family Dilepididae (Railliet \& Henry, 1909). In: Khalil LF, Jones A, Bray RA. Keys to the cestode parasites of vertebrates. Wallingford: CAB International; 1994. p. 443-554.

Botero Correa LC, Fernández AD, Forero NM, Rosas SG, Soler-Tovar D. Análisis retrospectivo de las enfermedades parasitarias del mono ardilla (Saimiri sciureus) en dos condiciones ex situ en el noroccidente de los Andes suramericanos. Rev Med Vet 2011; 22: 85-93.

Bowman DD. Helminths. In: Bowman DD. Georgis' Parasitology for Veterinarians. 9th ed. Saunders Elsevier; 2009. p. 115-239.

Carpenter JW. Exotic animal formulary. 3th ed. Elsevier Science Health Science Division; 2004.

Carvalho-Filho PR, Cardozo SV, Ribeiro CT, Medeiros SM, Lopes CWG. Intestinal Protozoa in apprehended New World nonhuman primates. Braz J Vet Res Anim Sci 2006; 43(3): 354-361.

Chapman CA, Speirs ML, Gillespie TR, Holland T, Austad KM. Life on the edge: gastrointestinal parasites from the forest edge and interior primate groups. Am J Primatol 2006; 68(4): 397-409. PMid:16534810. http://dx.doi.org/10.1002/ajp.20233

Didyk AS, Burt MDB. Paraliga charadrii n. sp. (Cestoda: Dilepididae) from the Semipalmated Plover, Charadrius semipalmatus Bonaparte (Aves: Charadriiformes). J Parasitol 1998; 84(4): 828-830. PMid:9714219. http://dx.doi.org/10.2307/3284597

Dupont F, Crivelli AJ. Do parasites confer a disadvantage to hybrids? A case study of Alburnus alburnus $x$ Rutilus rutilio, a natural hybrid of Lake Mikri Prespa Northern Greece. Oecologia 1988; 75(4): 587-592. http:// dx.doi.org/10.1007/BF00776424

Gotoh S, Takenaka O, Watanabe K, Hamada Y, Kawamoto Y, Watanabe $\mathrm{T}$, et al. Hematological values and parasite fauna in free-ranging Macaca 
hecki and the $M$. hecki / M. tonkeana hybrid group of Sulawesi Island, Indonesia. Primates 2001; 42(1): 27-34. http://dx.doi.org/10.1007/ BF02640686

Hershkovitz P. Living New World Monkeys (Platyrrhini), volume 1: with an introduction to primates. Chicago: University of Chicago Press; 1977.

Horna M, Tantaleán M. Parásitos de primates peruanos: helmintos del "mono fraile" y del "pichico barba blanca". In: Rodríguez NC. La Primatología en El Perú: InvestigacionesPrimatológicas (1973-1985). Lima: Proyecto Peruano de Primatología Manuel Moro Sommo; 1990. p. 555-564.

Kindlovits A. Clinica e terapêutica em primatas neotropicais. Juiz de Fora: Ed. UFJR; 1999.

Machado Filho DA. Revisão do gênero Prosthernorchis Travassos, 1915 (Acanthocephala). Mem Inst Oswaldo Cruz 1950; 48: 495-544. http:// dx.doi.org/10.1590/S0074-02761950000100020

Mattia S, Colli CM, Adami CM, Guilherme GF, Nishi L, RubinskyElefant G, et al. Seroprevalence of Toxocara infection in children and environmental contamination of urban areas in Paraná State, Brazil. J Helminthol 2012; 86(4): 440-445. PMid:22114910. http://dx.doi. org/10.1017/S0022149X11000666

McCarthy J, Moore TA. Emerging helminth zoonoses. Int J Parasitol 2000; 30(12-13): 1351-1360. http://dx.doi.org/10.1016/S00207519(00)00122-3

Melo AL, Pereira LH. Sobre o parasitismo por Primasubulura jacchi em Callithrix penicillata (Primates, Callitrichidae). In: Melo MT. A Primatologia no Brasil. 2. ed. Brasília: Sociedade Brasileira de Primatologia; 1986. p.483-488.

Melo AL. Helminth parasites of Callithrix geoffroyi. Lab Primate News 2004; 43(2): 7-9.

Melo FR. Caracterização molecular de Callithrix aurita, C. flaviceps, C. geoffroyi e seus prováveis híbridos (Primates, Callitrichinae) [Dissertação]. Viçosa: Universidade Federal de Viçosa; 1999.

Michaud C, Tantalean M, Ique C, Montoya E, Gozalo A. A survey for helminth parasites in feral New World non-human primate populations and its comparison with parasitological data from man in the region. J Med Primatol 2003; 32(6): 341-345. PMid:14641789. http://dx.doi. org/10.1046/j.1600-0684.2003.00037.x

Monteiro RV, Dietz JM, Beck BB, Baker AJ, Martins A, Jansen AM. Prevalence and intensity of intestinal helminths found in free-ranging golden lion tamarins (Leontopithecus rosalia, Primates, Callitrichidae) from Brazilian Atlantic forest. Vet Parasitol 2007; 145(1-2): 77-85. PMid:17223269. http://dx.doi.org/10.1016/j.vetpar.2006.12.004

Monteiro RV, Jansen AM, Pinto RM. Coprological helminth screening in Brazilian free ranging golden lion tamarins, Leontopithecus rosalia (L., 1766) (Primates, Callithrichidae). Braz J Biol 2003; 63(4): 727-729. PMid:15029386. http://dx.doi.org/10.1590/S151969842003000400022

Moulia C, Aussel JP, Bonhomme F, Boursot P, Nielsen JT, Renaud F. Wormy mice in a hybrid zone, a genetic control of susceptibility to parasite infection. J Evol Biol 1991; 4(4): 679-687. http://dx.doi. org/10.1046/j.1420-9101.1991.4040679.x

Moulia C, Le Brun N, Dallas J, Orth A, Renaud F. Experimental evidence of genetic determinism in high susceptibility to intestinal pinworm infection in mice: a hybrid zone model. Parasitology 1993; 106(Pt 4): $387-$ 393. PMid:8316436. http://dx.doi.org/10.1017/S0031182000067135
Moulia C. Parasitism of plant and animal hybrids: are facts and fates the same? Ecology 1999; 80(2): 392-406. http://dx.doi.org/10.1890/00129658(1999)080[0392:POPAAH]2.0.CO;2

Müller B, Mätz-Rensing K, Pérez Yamacita JG, Heymann EW. Pathological and parasitological findings in a wild red titi monkey, Callicebus cupreus (Pitheciidae, Platyrrhini). Eur JWildl Res 2010; 56(4): 601-604. http://dx.doi.org/10.1007/s10344-009-0357-1

Overgaauw PAM. Aspects of Toxocara epidemiology: human toxocarosis. Crit Rev Microbiol 1997, 23(3): 215-231. PMid:9347221. http://dx.doi. org/10.3109/10408419709115137

Pacheco LR, Néri FM, Frahia VT, Melo AL. Parasitismo natural em sauás, Callicebus nigrifrons (Spix, 1823): Variação na eliminação de ovos de Nematoda e Cestoda. Neotrop Primates 2003; 11(1): 29-32.

Pereira RF, Gonçalves AM, Melo FR, Feio RN. Primates from the vicinity of Viçosa, Minas Gerais, Brazil. Neotrop Primates 1995; 3(4): 171-173.

Resende DM, Pereira LH, Melo AL, Tafuri WL, Moreira NB, Oliveira CL. Parasitism by Primasubulura jacchi (Marcel, 1857) Inglis, 1958 and Trichospirura leptostoma Smith and Chitwood, 1967 in Callithrix penicillata marmosets, trapped in wild environment and maintained in captivity. Mem Inst Oswaldo Cruz 1994; 89(1): 123-125. PMid:7823812. http://dx.doi.org/10.1590/S0074-02761994000100024

Richart R, Benirschke K. Causes of death in a colony of marmoset monkeys. J Pathol Bacteriol 1963; 86(1): 221-223. http://dx.doi. org/10.1002/path.1700860128

Sage RD, Heyneman D, Lim KC, Wilson AC. Wormy mice in a hybrid zone. Nature 1986; 324(6092): 60-63. PMid:12356091. http://dx.doi. org/10.1038/324060a0

Santos SMC, Nogueira CP, Carvalho ARD, Strier KB. Nota sobre helmintos encontrados em primatas da Estação Biológica de Caratinga, MG. In: Mendes SL, Chiarello AG. A Primatologia no Brasil. 8. ed. Santa Teresa: Sociedade Brasileira de Primatologia; 2004. p. 333-340.

Santos Sales I, Ruiz-Miranda CR, Santos CP. Helminths found in marmosets (Callithrix penicillata and Callithrix jacchus) introduced to the region of occurrence of golden lion tamarins (Leontopithecus rosalia) in Brazil. Vet Parasitol 2010; 171(1-2): 123-129. PMid:20378249. http:// dx.doi.org/10.1016/j.vetpar.2010.02.044

Sarmiento L, Tantaleán M, Huiza A. Nematodos parásitos del hombre y de los animales en el Perú. Rev Peru Parasitol 1999; 14: 9-65.

Schmidt GD. Handbook of Tapeworm Identification. Florida: CRC Press; 1986.

Scholz T, Salgado-Maldonado G. Metacestodes of the family Dilepididae (Cestoda: Cyclophyllidea) parasitising fishes in Mexico. Syst Parasitol 2001; 49(1): 23-39. PMid:11389328. http://dx.doi. org/10.1023/A:1010603732525

Sloss MW, Zajac AM, Kemp RL. Parasitologia clínica veterinária. São Paulo: Editora Manole Ltda; 1999.

Stuart M, Pendergast V, Rumfelt S, Pierberg S, Greenspan L, Glander K, et al. Parasites of Wild Howlers (Alouatta spp.). Int J Primatol 1998 19(3): 493-512. http://dx.doi.org/10.1023/A:1020312506375

Traversa D. Pet roundworms and hookworms: A continuing need for global worming. Parasit Vectors 2012, 5: 91-110. PMid:22574783 PMCid:PMC3418564. http://dx.doi.org/10.1186/1756-3305-5-91

Thoisy B, Vogel I, Reynes JM, Pouliquen JF, Carme B, Kazanji M, et al. Health evaluation of translocated free-ranging primates in French 
Guiana. Am J Primatol 2001; 54(1): 1-16. PMid:11329164. http:// dx.doi.org/10.1002/ajp.1008

Vicente JJ, Rodrigues HO, Gomes DC. Nematóides do Brasil. $1^{a}$ parte: Nematóides de peixes. Atas Soc Biol 1985; 25: 1-79.

Wenz A, Heymann EW, Petney TN, Taraschewski HF. The influence of human settlements on the parasite community in two species of Peruvian tamarin. Parasitology 2010; 137(4): 675-684. PMid:20025821. http:// dx.doi.org/10.1017/S0031182009991570

Wenz-Mücke A, Sithithaworn P, Petney TN, Tarachewski H. Human contact influences the foraging behaviour and parasite community in long-tailed macaques. Parasitology 2013; 140(6): 709-718. PMid:23363557. http://dx.doi.org/10.1017/S003118201200203X 